\title{
LAS «DAMITAS» DE MOIXENT EN EL CONTEXTO DE LA PLÁSTICA Y LA SOCIEDAD IBÉRICA ${ }^{1}$
}

\author{
$M^{a}$ ISABEL IZQUIERDO PERAILE \\ Instituto de Historia, CSIC, Madrid
}

\begin{abstract}
Nuestro objetivo en este trabajo es plantear un nueva valoración de los altorrelieves esculpidos en bloques arquitectónicos conocidos como las "damitas", procedentes de un empedrado tumular de la necrópolis ibérica del Corral de Saus (Moixent, Valencia). Proponemos una lectura distinta, en clave de género, de estas figuras en el contexto de las representaciones femeninas y juveniles de la plástica ibérica, así como su comprensión en la sociedad que genera estas imágenes.
\end{abstract}

Notre objectif dans ce travail est de proposer une nouvelle valorisation des hautsreliefs sculptés en blocs architectoniques connus comme les «damitas» ("petites dames»), qui se trouvaient dans un empierré tumulaire de la nécropole ibérique du Corral de Saus (Moixent, Valencia). Nous proposons une lecture différente, axée sur le genre, de ces figures dans le contexte des représentations féminines et juvéniles de la plastique ibérique, ainsi que leur compréhension dans la société qui crée ces images.

\section{I- INTRODUCCIÓN}

El punto de partida de este trabajo se centra en el estudio de las piezas conocidas por la investigación como las «damitas» de la necrópolis del Corral de Saus de Moixent. La valoración que trataremos de realizar de estas esculturas tiene sentido desde una perspectiva triple de análisis, en relación con una serie de líneas de investigación, que brevemente pasamos a citar.

En primer lugar, partimos de los postulados de la disciplina denominada arqueología de la muerte ${ }^{2}$ (cfs., para una síntesis global, CHAPMAN, KINNES y RANDSBORG, 1981) desde sus planteamientos clásicos, asumiendo algunas de las críticas y propuestas alternativas surgidas en el seno, fundamentalmente, de la arqueología postprocesual ${ }^{3}$. Así, en definitiva, consideramos el enfoque del mundo funerario desde la perspectiva del entramado socio-cultural e ideológico de los vivos, tratando de vincular los datos que nos ofrece el registro arqueológico en relación al fenómeno de la muerte con los patrones o modelos del comportamiento humano de las sociedades del pasado (CHAPMAN y RANDSBORG, 1981, 2). Desde esta perspectiva, las prácticas funerarias
'Este artículo se integra en el proyecto de investigación:
"Tumbas destruidas y esculturas fragmentadas en la Cultu-
ra ibérica: el ejemplo del Corral de Saus de Moixent (Valen-
cia)", dirigido por la Dra. C. Aranegui, que hemos desarro-
Ilado a través de una beca de F.P.I., otorgada por la
Conselleria de Educació i Ciència de la Generalitat Valen-
ciana. Asimismo, se enmarca en el proyecto denominado "La
sociedad ibérica a través de sus cerámicas" (PB94-0977),
subvencionado por la DGICYT, en el que participamos.

${ }^{2}$ La originalmente llamada Archaeology of death surge a principios de la decada de los setenta como una propuesta teórica y metodológica dentro de la New Archaeology, orientando el estudio de los restos funerarios desde una perspectiva distinta a la tradicional, un nuevo enfoque que aporta valiosos datos sobre el entramado social de las culturas del pasado. Las aportaciones esenciales para su nacimiento las plantean, entre otros, BINFORD (1972). Con la obra The Archaeology of death (CHAPMAN, KINNES y RANDSBORG, 1981) llegamos a una especie de estado de la cuestión del tema, con nuevas aportaciones y valoraciones. Sin embargo, la Arqueología de la muerte también ha recibido y recibe en la actualidad críticas, así, se han aportado propuestas alternativas a las primeras formulaciones. A nivel peninsular y del mundo ibérico, destacan las primeras aportaciones teóricas de LULL y PICAZO (1989) y CHAPA (1991) eritre otros, sin ánimo de ser exhaustivos.

${ }^{3}$ De la mano de 1. Hodder, o sus discípulos M. Shanks y $C$. Tilley. Otra interesante aportación es la de P. Ucko que se muestra crítico apoyándose en numerosos, singulares y conocidos ejemplos etnográficos. Desde el punto de vista de la antropología destaca la problemática planteada por Humphreys o HUNTINGTON y METCALF (1979). 


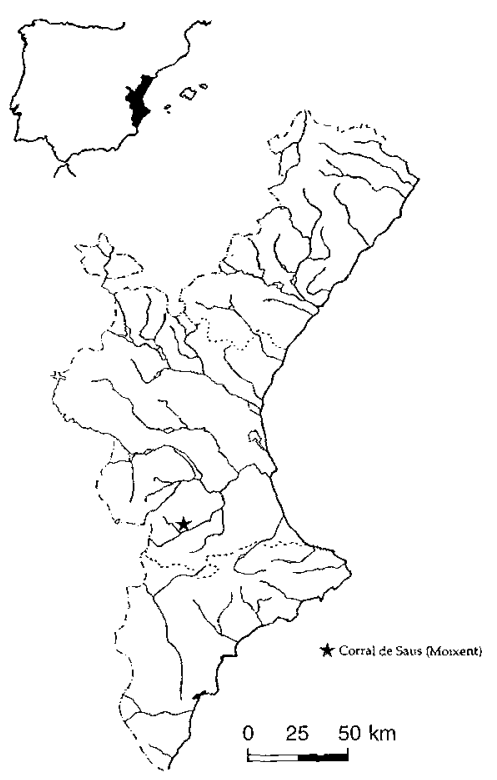

Figura 1: Situación de la necrópolis ibérica del Corral de Saus (Moixent, Valencia).

pueden ser entendidas como un reflejo, en mayor o menor grado directo, de la organización y la estructura de la sociedad que concibe dichas manifestaciones. En palabras de J.- P. Vernant: «(...) le monde des morts (ou du moins ce qui nous en reste) se présente comme le reflet, l'expression plus ou moins directe, plus ou moins médiatisée, travestie, voire phantasmatique, de la société des vivants." (VERNANT, 1982, 6).

En segundo término, esta investigación tiene como eje fundamental la documentación iconográfica, en este caso, a través de imágenes esculpidas en piedra y erigidas en una necrópolis ibérica. Seguimos, pues, distintos trabajos que han valorado e interpretado las representaciones de la sociedad antigua a través de sus propias imágenes, línea de trabajo que cuenta con valiosas aportaciones para el ámbito del Mediterráneo antiguo, desde el arcaísmo hasta época helenística, esencialmente para Grecia, Etruria y la Magna Grecia (AAVV, 1984; AAVV, 1987; AAVV, 1988; BULLOCH, GRUEN, LONG y STEWARD, 1993, entre otros) y también, para el caso de la sociedad ibérica (OLMOS, TORTOSA e IGUACEL, 1992; v., como síntesis reciente desde el punto de vista de la historiografía y las posibles perspectivas futuras de la investigación, OLMOS, 1996) y, concretamente, para el período centrado en el s. III a.C. (ARANEGUI, 1996). Por tanto, de nuevo, este binomio formado por la iconografía o el universo de la imagen y la sociedad tiene sentido, desde nuestro punto de vista, de cara a un mejor conocimiento de la cultura ibérica.

En esta línea, consideramos que la representación de figuras femeninas en las culturas del pasado no es indiscriminada ni autónoma, sino que por el contrario, su aparición se inserta en un determinado sistema de autorepresentación de la sociedad. En el caso de la cultura ibérica, ante una sociedad plural, compleja y jerarquizada, el análisis, en clave de género, de estas imágenes, puede suponer una aportación más en epoyo de conocer esta complejidad y jerarquización social (ARANEGUI, 1994; EADEM, 1996 y $1997 \mathrm{a}, \mathrm{b})$.

\section{II- LAS «DAMITAS» DEL CORRAL DE SAUS (MOIXENT, VALENCIA). EL HALLAZGO, LA MATERIA Y DESCRIPCIÓN}

Las «damitas» fueron descubiertas en la segunda campaña de excavaciones llevada a cabo por el S.I.P. en la necrópolis del Corral de Saus (fig. 1) en 1973, bajo la dirección de D. Fletcher y E. Pla y la realización sobre el terreno de J. Aparicio. Las dos esculturas fueron halladas reempleadas en el empedrado tumular de la conocida "gran sepultura de las damas" o "tumba de las damitas", en el sector C de la llamada necrópolis inferior, reutilizadas, a modo de grada inferior en el ángulo noroeste de la estructura, en el caso de uno de los fragmentos, el mayor conservado, -damita I-, o como parte del empedrado del monumento en el ángulo diagonalmente opuesto al citado -damita II- (FLETCHER, 1975, 110-111). La «tumba de las damitas" presenta forma cuadrangular ${ }^{4} \mathrm{y}$ es de dimensiones inferiores a la llamada «tumba de las sirenas", localizada ésta en 1972 en el sector A (fig. 2). Conserva tres gradas de sillares, con una altura máxima de $68 \mathrm{~cm}$ (APARICIO, 1976). En su interior, hacia el ángulo noroeste se localizó un hoyo con restos cremados y parte del ajuar, expoliado desde antiguo (FLETCHER, 1975, 111; PLA, 1976, $391)$. A través del estudio antropológico de los restos óseos calcinados llevado a cabo por $M$. Calvo, se ha determinado el enterramiento de un individuo de sexo masculino de edad adulta -de entre 20 a 39 años-, con buena combustión y una temperatura alcanzada en la pira supe-

\footnotetext{
${ }^{4}$ La estructura está orientada al noroeste, a unos $30^{\circ}$ del norte magnético, conservando en la actualidad $320 \mathrm{~cm}$ de longitud en su cara norte, $244 \mathrm{~cm}$ en la cara este y $206 \mathrm{~cm}$ en la oeste, estando la cara sur totalmente arrasada.
} 
$+P_{0}+O_{0}+\bar{N}_{0}+N_{0}+M_{0}+L_{0}+L_{0}+K_{0}+J_{0}+B_{0}+H_{0}+G_{0}+F_{0}+E_{0}+O_{0}+C_{0}+B_{0}+A_{0}+A+B+C+O+E+F+G_{+}+H+1+J+K+L+L L+M+N+$

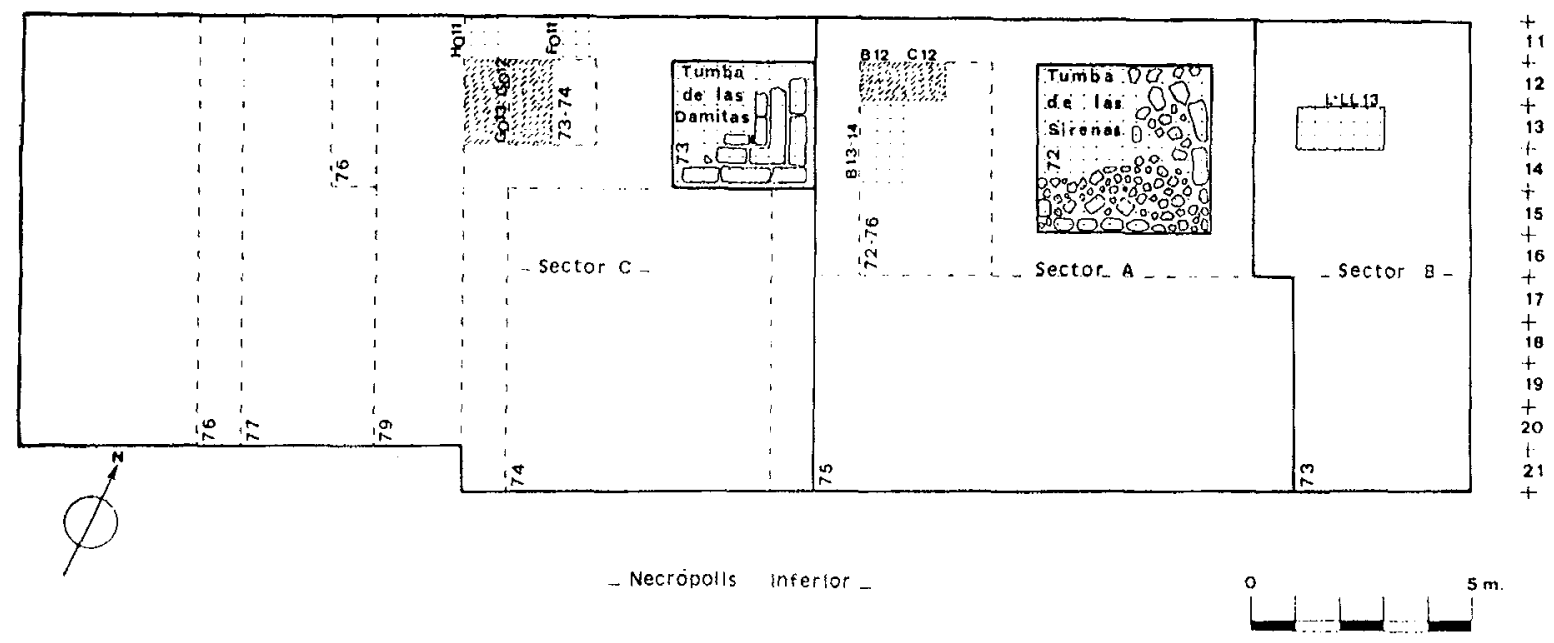

Figura 2: Plano actualizado de zonas excavadas de la denominada necrópolis inferior del Corral de Saus (APARICIO, 1984, fig. 16).
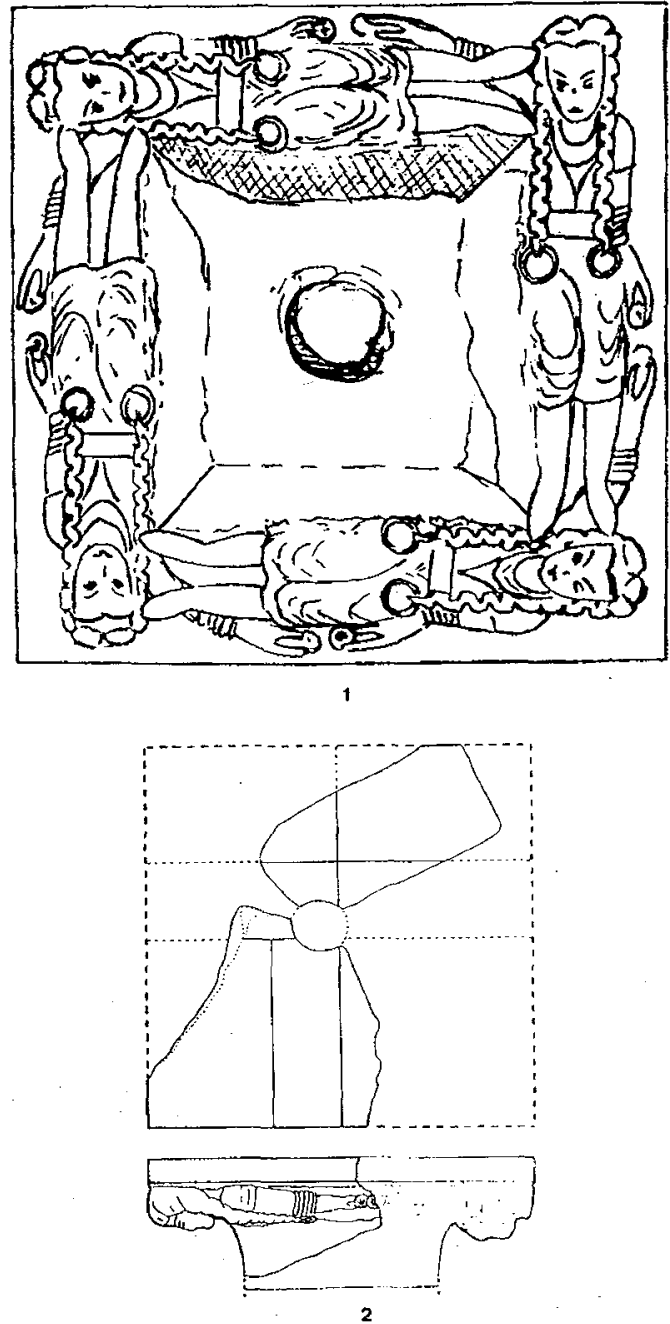

Figura 3: Propuestas de restitución de la deposición de las "damitas" de Moixent. 3.1: Primera propuesta, según Fletcher y Pla (1974, 39). 3.2: Propuesta posterior de Almagro (1983b, fig. 14).

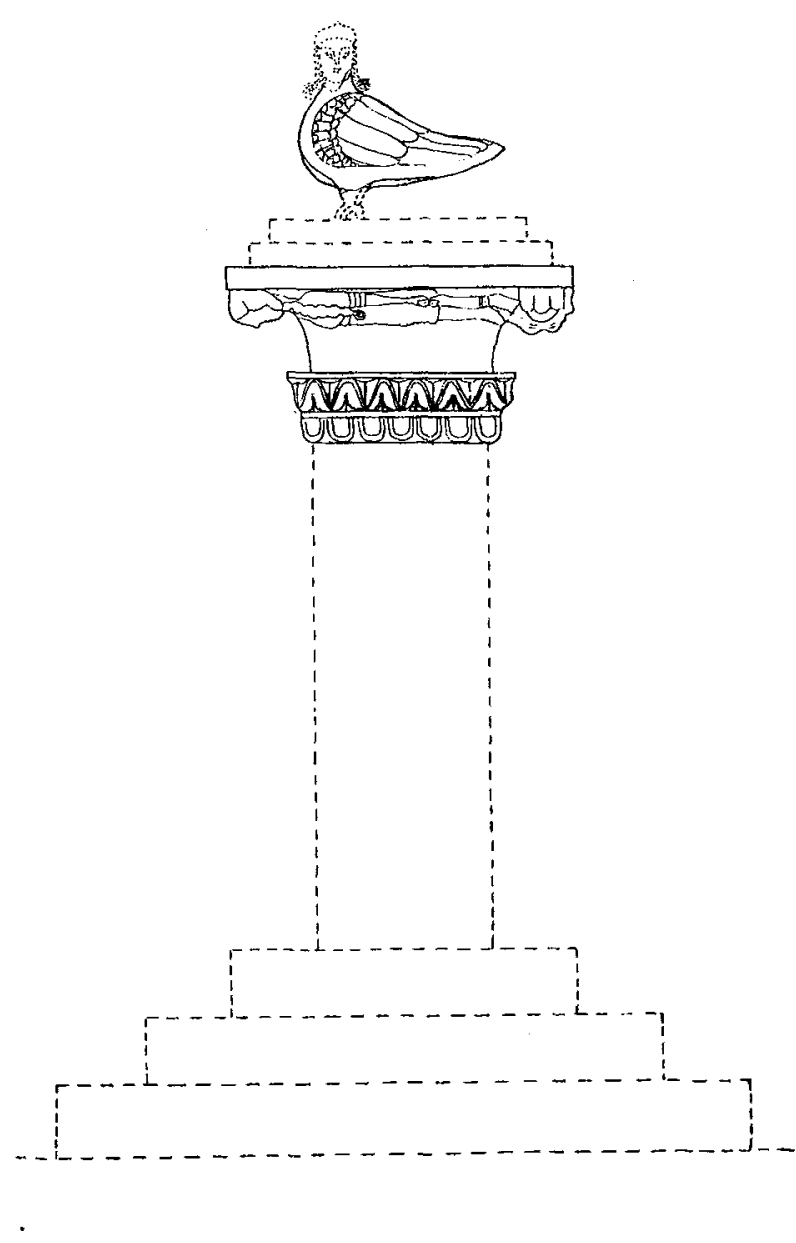

Figura 4: Propuesta de restitución del monumento tipo pilarestela del Corral de Saus, con las "damitas" a modo de nacela de gola decorada, según Almagro (1987, fig. 3). 
rior a los $650^{\circ}$ (IZQUIERDO, 1998a, Anexo IV, 860-861). Asimismo, el antracoanálisis efectuado por la Dra. E. Grau, a través de las muestras de carbón analizadas, ha demostrado la presencia de Pinus halepensis y Quercus ilexcoccifera, las maderas más utilizadas en las cremaciones de esta necrópolis (EADEM, Anexo V, 880-881).

Centrándonos en las piezas objeto de nuestro análisis, la importancia del hallazgo de las piezas es recogida en la prensa local ese mismo año, con artículos como: Las damas ibéricas de Moixent (PELEJERO, 1973a) o La necrópolis ibérica de Moixent. Su antigüedad se calcula en el siglo IV antes de Cristo (IDEM, 1973b). La investigación prestará atención a estas esculturas a través de numerosos trabajos y, sobre todo, menciones de su descripción y singularidad, desde prácticamente su descubrimiento en adelante (FLETCHER, 1974, 111; FLETCHER y PLA, 1974, 38-39; IDEM, 1977; PLA BALLESTER, 1976, Fig. 2 y 4; IDEM, 1977a y b,; APARICIO, 1976; IDEM, 1982; IDEM, 1984, 189, Fig. 23-24; ALMAGRO, 1983b, fig. 14 y 16; IDEM, 1987, 202 y ss; RUANO, 1987, Fig. 24, V-2; entre otros).

Con respecto a su determinación petrológica ${ }^{5}$, el conjunto monumental del Corral de Saus se elabora a partir de las típicas rocas carbonatadas areniscas y calizas, cuyas tonalidades son variables, oscilando entre los beiges claros a amarillos de distinta intensidad. Ello responde, en alguna medida, a los diferentes grados de alteración. Estos soportes pétreos son habituales en la elaboración de gran parte del repertorio de escultura y arquitectura monumental funeraria en el mundo ibérico, cuyas características intrínsecas de tenacidad y resistencia permiten un fácil trabajo escultórico, pero que al mismo tiempo pueden sufrir diversas alteraciones de los minerales componentes, mermando su compacidad y deshaciéndose con facilidad. En relación a la procedencia de las piedras, tras un primer análisis de los litotipos presentes en el entorno de la necrópolis objeto de análisis, que ha consistido en un estudio detallado de la bibliografía y cartografía geológica de la zona, y el trabajo de campo iniciado -localización y muestreo de diversas formaciones geológicas-, planteamos la hipótesis de un posible origen local, del entorno del yacimiento, para la piedra utilizada en la elaboración, tanto de estas esculturas, como para la mayor parte del conjunto del Corral de Saus (IZQUIERDO, 1995, T. I, 66), confirmada por los análisis de lámina delgada efectuados (OROZCO en IZQUIERDO, 1997, Anexo III, 847-850).

Su consideración como "damitas» aparece desde los primeros trabajos publicados tras el descubrimiento (FLETCHER y PLA, 1974) en función de la apariencia juvenil, aniñada de las figuras, su peinado de largas trenzas sin recoger, etc., en oposición a la serie de las grandes damas por excelencia del mundo ibérico, entre las que destaca por encima de todas la de Elx (Alicante) (GARCÍA BELLIDO, 1943, 363; OLMOS y TORTOSA, 1997), además de la de Baza (Granada) (PRESEDO VELO, 1982, 52-56), la gran dama oferente del Cerro de los Santos (Montealegre del Castillo, Albacete) (GARCÍA BELLIDO, 1943, 275), la de Cabezo Lucero (Guardamar del Segura, Alicante) (LLOBREGAT, 1989), a las que podrían seguir las de EI Cigarralejo (Mula, Murcia) (CUADRADO, 1995), la de «la adormidera» de L'Alcúdia (Elx, Alicante) (BENOIT, 1957, fig. 1) o las de Vizcarra (Alicante), Benimassot (Alcoi) y Caudete (Museo de Villena) (ARANEGUI, 1997a), un conjunto de damas, en definitiva, que se compone de piezas de características muy distintas.

Volviendo a nuestras "damitas", con respecto a su original disposición, si bien Fletcher y Pla plantean por vez primera su composición conjunta, en su opinión, flanqueando los cuatro lados de una hipotética plataforma o pirámide central con el enlace de un brazo por debajo de las piernas de la figura adyacente y el otro extendido a lo largo del cuerpo, sosteniendo en su mano la citada adormidera o granada, según el esquema conocido y aceptado (FLETCHER y PLA, 1974, 39) (fig. 3, 1), la definición de las esculturas desde el punto de vista de su inserción en un marco arquitectónico fue explicitada y completada por Almagro, quien realiza la primera propuesta de restitución del monumento tipo pilar-estela del yacimiento (ALMAGRO, 1983a, fig. 1; IDEM, 1983b, fig. 16; IDEM, 1987, fig. 3).

Siguiendo a este último autor, se considera que las «damitas» formarían parte de una nacela de gola decorada, en este caso con figuras femeninas yacentes esculpidas en altorrelieve (fig. 3, 2). El interior de las piezas presenta una perforación circular vertical de

\footnotetext{
${ }^{5}$ En este sentido, cabe citar el estudio petrológico realizado, con la colaboración de T. Orozco Köhler, del Departament de Prehistòria i d'Arqueologia de la Universitat de València, paralelo al desarrollo de nuestro proyecto de investigación, que ha proporcionado interesantes resultados.
} 


\begin{tabular}{|c|c|c|c|c|c|c|c|c|c|c|c|c|}
\hline \multirow[t]{2}{*}{ PIEZA } & \multicolumn{3}{|r|}{ LOCALIZACION } & \multirow{2}{*}{$\begin{array}{c}\text { MBICACION } \\
\text { s.l.P. }\end{array}$} & \multirow{2}{*}{$\begin{array}{c}\text { ELEMENTO } \\
\text { ARQ. }\end{array}$} & \multicolumn{3}{|c|}{ DIMENSIONES } & \multicolumn{2}{|l|}{ MATERIA } & \multirow{2}{*}{$\begin{array}{c}\text { GRADO } \\
\text { FRACTURACION }\end{array}$} & \multirow[t]{2}{*}{ OBSERVACIONES } \\
\hline & SEC & $\overline{\mathrm{CAM}}$ & TUMBA & & & LO.MAX-MIN & AN.MAX-MIN & AL.MAX-MIN & DET. PETROL. & COLOR & & \\
\hline Damita I & c & 1973 & Empedrado "T. damitas" & 13581 & Nacela dec. & $64 \mathrm{~cm}$. & $57 \mathrm{~cm}$ & $36 \mathrm{~cm}$ & Caliza & Blanquecina & Medho & Restos policromia \\
\hline Damita II & c & 1973 & Empedrado "T. damitas" & 13582 & Nacela dec. & $58,5 \mathrm{~cm}$. & $47 \mathrm{~cm}$. & $27,5 \mathrm{~cm}$ & Caliza & Blanquecina & Alto & Restos policromfa \\
\hline
\end{tabular}

Tabla 1: Síntesis de datos descriptiva de las piezas denominadas «damita» I y «damita» II, procedentes de la necrópolis ibérica del Corral de Saus.

aprox. $16 \mathrm{~cm}$ de $\varnothing$, aún apreciable en la actualidad, que posiblemente atravesara el elemento de arriba abajo. Su cara inferior no se conserva, aunque un fragmento considerado posteriormente como nacela de gola lisa -S.I.P. 13.687- (IZQUIERDO, 1995, 89, fig. 14, 3; EADEM, 1998a, fig. 101, 1) podría pertenecer al conjunto de esta nacela decorada, suponiendo un fragmento visible de dicha superficie inferior en la nacela. La cara superior de los fragmentos posee líneas incisas, posibles marcas de trazado para el asiento de otros bloques arquitectónicos superiores (ALMAGRO, 1987, 203). Asimismo, el conocido pilar propuesto por este autor se compone de una hipotética base escalonada, pilar cuadrado, coronamiento con el sillar de gola formado por un baquetón ricamente decorado con doble fila de ovas, nacela con la excepcional moldura decorada y filete liso, siendo más incierta, en nuestra opinión, la atribución del remate del monumento, con posible sirena en bulto redondo y la cabecita femenina tocada con alto polos recuperada en el yacimiento (fig. 4).

Pasamos a continuación a la descripción de las dos piezas (IZQUIERDO, 1995, T. I, 8488) (véase tabla 1):

- «Damita»। (S.I.P. núm. 13.581) (fig. 5, Láminas I y II).

Las dimensiones generales son: $64 \mathrm{~cm}$ de long. $x 57 \mathrm{~cm}$ de anch. $\times 36 \mathrm{~cm}$ de alt., presentando un filete liso de $6 \mathrm{~cm}$ de alt. y una nacela decorada de $30 \mathrm{~cm}$ de alt. conservada. La figura femenina que decora este sillar arquitectónico viste una túnica larga de tela fina, parcialmente plisada, con posible falda de tipo acampanado, ajustada, a modo de paño que se ciñe y refleja a través de sus pliegues, la anatomía de las extremidades inferiores, abdomen y parte superior de su cuerpo. La túnica es de manga corta y cuello posiblemente redondeado, observándose varios pliegues a la altura del hombro y destacándose el ancho cinturón, liso, que se ajusta a la cintura de manera muy evidente, recoge la túnica y subraya el cuerpo de esta figura femenina. Es interesante el tratamiento diferencial de los volúmenes que destaca la anatomía de la misma, en contraposición a la "damita" II, cuya labra es mucho más plana, como veremos.
Presenta un peinado de largas trenzas que se inician en lo alto de la cabeza, rodeándola completamente y terminan a la altura de la cadera en gruesas anillas, colgantes o aros lisos. Por debajo del nacimiento de estas abultadas trenzas se representa la diadema, que cubre el nacimiento del cabello, decorada a modo de capas $u$ ondas transversales paralelas, dejando visible una frente amplia, plana y despejada. En su rostro, de forma ovalada, a pesar de las huellas de destrucción evidentes y el paso del tiempo, se aprecian los rasgos esquematizados de los ojos almendrados de tamaño destacado, la nariz y la boca. Se adorna con pendientes de disco o arracadas de tipo anular, lisos, sencillos, de grosor decreciente hacia el extremo superior, observables hasta la altura de la boca, aunque no se aprecian con claridad, apenas distinguiéndose en la "damita» II. Igualmente, posee un ancho collar abultado y largo, de sección más o menos triangular, sobre la túnica y un brazalete serpentiforme liso de seis espiras o vueltas en su antebrazo izquierdo.

Su brazo izquierdo, extendido a lo largo del cuerpo, sostiene en su mano un elemento globular, que parece tratarse por su forma, de un fruto, con botón central y ranuras laterales, posible granada (IZQUIERDO, 1997). Por el contrario, el brazo derecho parece arrancar por el extremo superior, levantarse en alto, uniéndose o pasando por debajo de los pies de otra figura, que reposaría, según el esquema conocido, ya explicitado por FLETCHER y PLA $(1974,39)$, tras el descubrimiento de las piezas, integrándolas en una forma cuadrada. Con respecto a la segunda figura femenina representada en este sillar, tan sólo se observa el posible calzado de la pierna derecha que reposa directamente sobre el costado derecho de la «damita», en contacto con su trenza. Este calzado cubre totalmente el pie de manera ajustada; es liso, aunque presenta algunas incisiones, achacables, en nuestra opinión, al deterioro de la pieza.

Se conservan restos de pintura roja, observables en la actualidad en diversos puntos del filete liso bajo la "damita», también sobre el lateral del cinturón, además de los laterales y parte superior de la túnica, en los dedos de la 



Figura 5: «Damita» I (dibujo de Francisco Chiner).

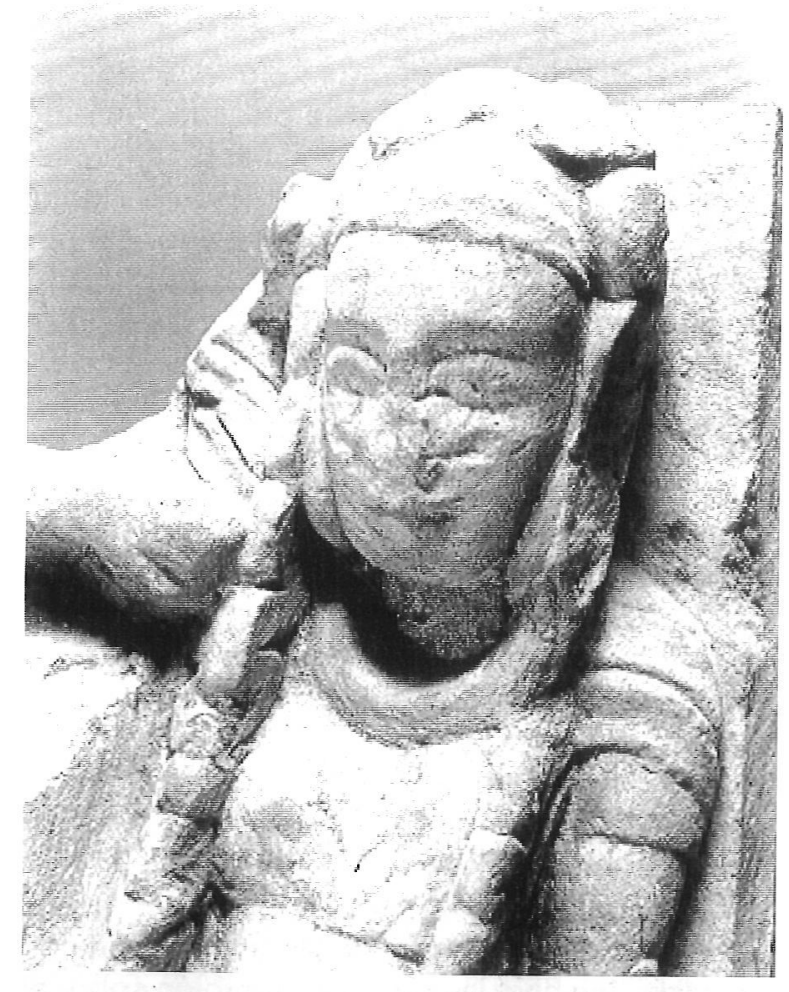

Lámina I: «Damita» I (foto archivo del S.I.P.).

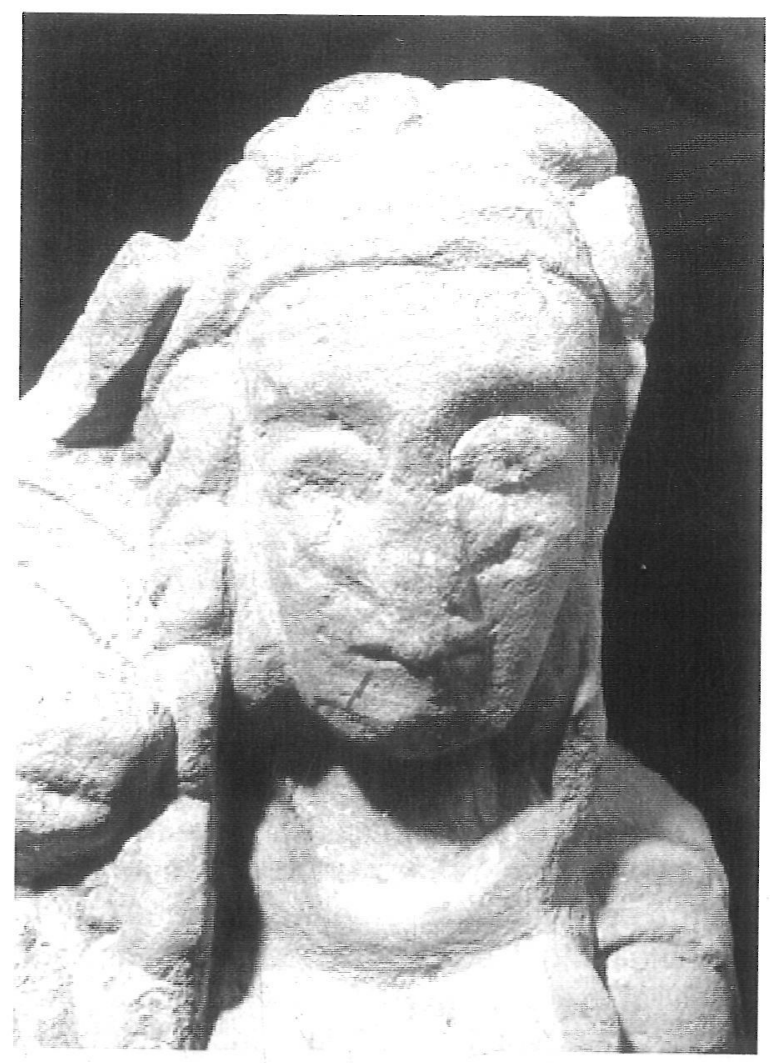

Lámina II: «Damita» I (foto I. Izquierdo). 

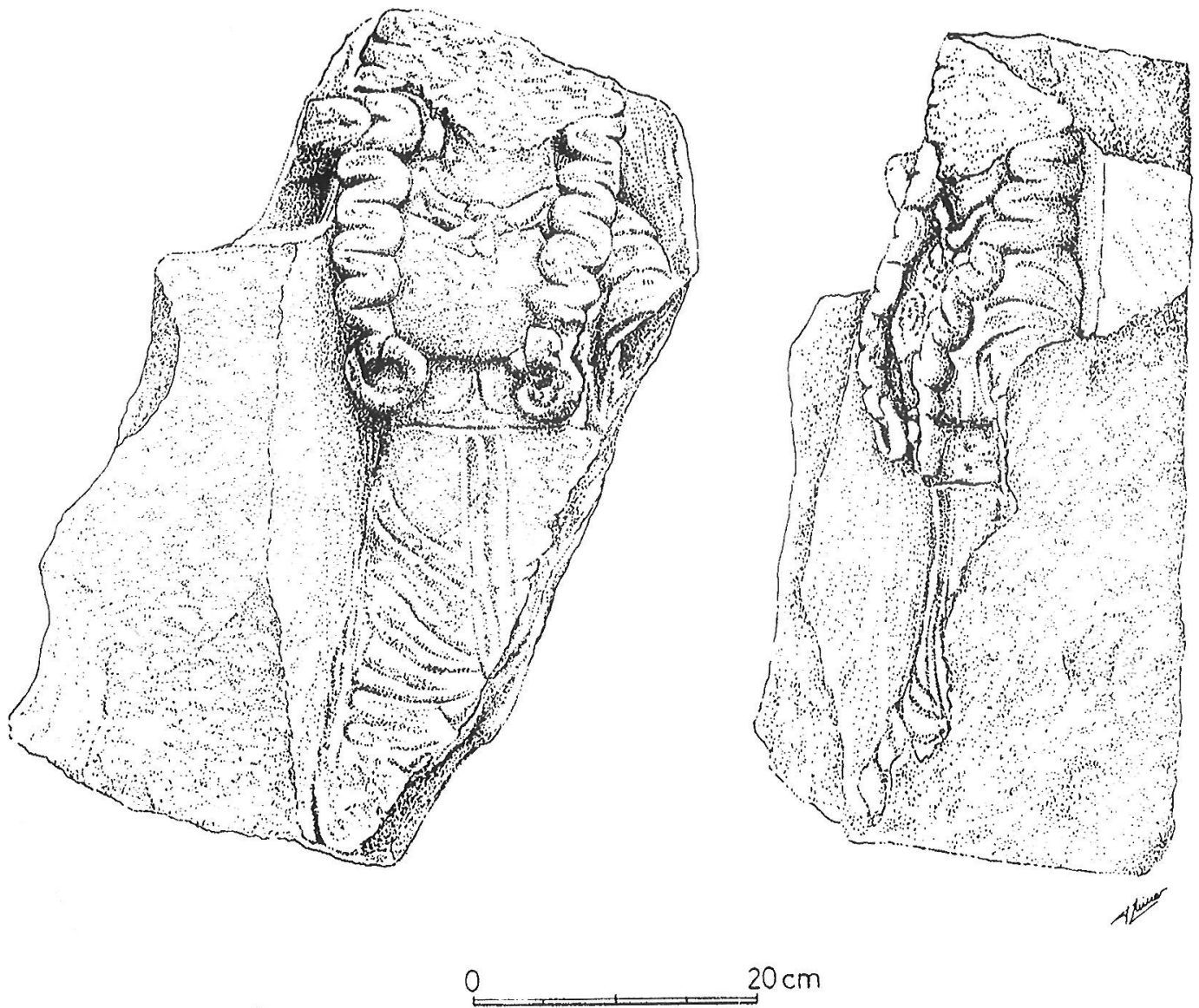

Figura 6: «Damita» II (dibujo de Francisco Chiner).

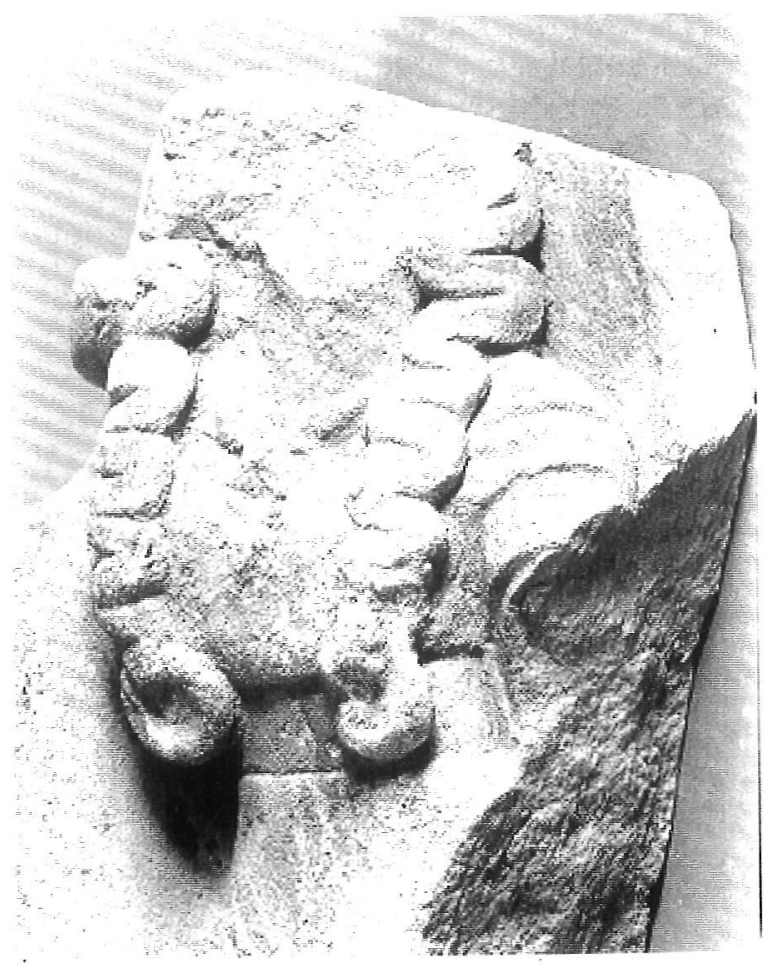

Lámina III: «Damita» II (foto archivo del S.I.P.). 
mano, y brazaletes, así como en el hombro. Asimismo, se observan posibles restos de pintura de color ocre o amarillento conservadas sobre la túnica.

\section{Lámina III).}

- «Damita» II (S.I.P. núm. 13.582) (fig. 6 ,

Esta pieza posee en su totalidad unas dimensiones generales de $58,5 \mathrm{~cm}$ de long. $x 47$ $\mathrm{cm}$ de anch. $x 27,5 \mathrm{~cm}$ de alt. conservada. Presenta, en general, una indumentaria, peinado y disposición similar a la anterior, aunque con diferencias evidentes. Viste una túnica de tela fina parcialmente plisada, con posible falda acampanada y larga, de escote redondo y manga corta, ceñida al cuerpo, aunque en esta ocasión no se observa el mismo tratamiento de volúmenes que ofrecía la pieza anterior. Se trata, en lugar de pliegues a modo de «paños mojados", de incisiones efectuadas en la piedra que tratan de simularlos, sin conseguirlo con tanta efectividad como en la «damita» I. Podría tratarse de una figura labrada por una mano distinta a la primera, aunque representa a una joven muy similar a ésta. De nuevo, el cinturón ancho ciñe la cintura, del cual surgen unas incisiones longitudinales que vienen a unirse a los pliegues de las piernas. El propio cinturón presenta dos motivos incisos, muy mal conservados, a modo de grandes ovas. Como adorno, sobre la túnica, de nuevo aparece un collar ancho, grueso, liso y largo, de sección más aplanada que en el anterior ejemplo, del cual pende, en posición central, un colgante de forma difícil de identificar por el estado de conservación - ¿circular?-

El peinado, a pesar del mayor nivel de fragmentación de la figura, de nuevo presenta trenzas longitudinales, rematadas por gruesas anillas, que terminan ahora a la altura del cinturón. La diferencia que manifiesta la forma de las trenzas de las dos figuras es achacable, en nuestra opinión, al diferente modo de representarlas, bien sea de manera más volumétrica «damita» I-, bien sea de manera más esquematizada y, sobre todo, más plana - "damita» II-. De igual manera que en la pieza anterior, el extremo del calzado de la hipotética cuarta figura apoya directamente sobre la trenza derecha de esta segunda "damita», presentando un aspecto liso y ajustado al pie, con algunas incisiones, fruto del deterioro de la pieza.

Este elemento arquitectónico se halla mucho más fragmentado que el anterior, no conservándose parte de la cabeza, ni de las extremidades. Se observan, por otra parte, res- tos de pintura roja muy evidentes en el cinturón y el lateral izquierdo de la túnica, así como, del mismo modo, posibles restos de pintura amarilla en una de las trenzas, en el pie o calzado y el propio filete, sobre el que descansa la figura.

La original disposición y las características de indumentaria, peinado, ornato y técnica de labra que presentan estas representaciones femeninas juveniles, trasluce algunos aspectos singulares que nos interesaría resaltar. En primer lugar, la diferencia de estilo y tratamiento en la talla de las «damitas» es evidente, como ya hemos señalado. Existe una diferenciación explícita entre las imágenes representadas, al menos en las dos figuras conservadas, que no sabemos si sería extensible a las otras dos figuras que completarían el conjunto esculpido. La interpretación de estas diferenciaciones en la labra es compleja - ise trata de artesanos o manos distintas, o variaciones intencionadas en la representación con algún tipo de connotación que escapa a nuestro conocimiento?-, aunque es interesante en este punto plantear estas apreciaciones. Por otro lado, la posición aparente de las figuras es, tras una primera lectura, yacente. Sin embargo, si bien de un modo evidente, su disposición longitudinal, adaptada materialmente al sillar indica una postura echada, tendida o reposada, en consonancia también, de una manera manifiesta, con el contexto funerario de las piezas, las "damitas" podrían plasmar una posición metafórica no necesariamente yacente sino estante, sugiriendo un hipotético transporte del difunto y un rito de tránsito al ofrendar granadas, teniendo en cuenta, además, la observación desde abajo de las piezas según la restitución del pilar.

Con respecto a sus elementos de indumentaria, la ausencia del velo y del típico manto, uno de los elementos constitutivos del atuendo femenino ibérico más importante (BANDERA, 1979, 267) podría sugerir una referencia a la edad juvenil de estas representaciones femeninas. Sin embargo, si observamos sus adornos personales, tanto el cinturón, la diadema como la joyería -destacados collares, con colgante central en un caso, brazalete de seis espiras y grandes anillas o colgantes en las trenzas- confieren a estas jóvenes carácter de prestigio. A su vez, los cinturones anchos -con o sin decoración- son poco frecuentes en la plástica ibérica. No aparecen en la estatuaria del Cerro de los Santos ni en la pintura de los vasos del Tossal de Sant Miquel de Llíria o similares, es- 
tando, sin embargo, bien representados en el monumento de Osuna al que pertenece el guerrero con falcata y la comitiva con auletris. Sin embargo se repiten, como veremos más adelante, en otra representación de nacela decorada como es la de la necrópolis de El Prado (Murcia).

Los colgantes o las anillas de las trenzas, por su parte, paralelizados a los que porta la auletris, posiblemente juvenil, representada en el vaso de La Serreta de Alcoi (v. infra), han sugerido a algunos autores la correspondencia con una especie de tintinabulum o sonaja, que sonaría con el movimiento del personaje (RUANO, 1987, 140-141, fig. 1 bis), aunque esta atribución nos parece más imprecisa. En definitiva, lo que consideramos más interesante es que sus elementos de adorno como la diadema y las joyas -collares, brazaletes y colgantes-que observamos aquí, se vinculan a su vez, en la sociedad ibérica, a las representaciones de damas ataviadas con sus mejores galas, a modo de espejo de una serie de elites y aristocracias reflejadas en estas imágenes femeninas que se asocian a la riqueza y el prestigio (ARANEGUI, 1996 y 1997 a y b).

Un símbolo interesante desde otro punto de vista, es el atributo que porta la "damita» I en su mano izquierda y viene a unirse en parte de otra figura en su mano opuesta. D. FLET. CHER y E. PLA $(1974,39)$ lo interpretaron como una especie de flor, posiblemente de adormidera. Con posterioridad, ALMAGRO $(1987,203)$, consideró que este objeto redondeado, con botón central era una granada. En nuestra opinión, pensamos, efectivamente, que se trata, en lugar de una flor, más bien del fruto del granado, a pesar de las dificultades que se dan en ocasiones para diferenciar representaciones en el arte entre la cápsula de adormidera -más alargada en general y de dimensiones menores- y la granada -con un volumen mayor y más redondeado, como parecen mostrar estas piezas-. Este fruto posee, por su parte, al igual que la adormidera, unas connotaciones y un simbolismo muy rico, conocido y bien documentado en ambientes sacros y funerarios de distintas culturas del Mediterráneo antiguo. Así, se ha asociado al mundo ctónico, la muerte y la resurrección o, por el contrario, a la fecundidad, el amor y la vida, dos significados opuestos que vienen a unirse en la imagen de la granada. Esta riqueza simbólica se adapta perfectamente, en definitiva, al contexto y al universo funerario y femenino plasmado en las piezas que estamos analizando aquí, y, de manera más concreta, pasando a ser un atributo de la mujer en el proceso de ampliación y feminización del ritual funerario que documenta la iconografía (IZQUIERDO, 1997).

\section{III- EL CONTEXTO DE LA PLÁSTICA IBÉRICA: OTRAS REPRESENTACIONES FEMENINAS}

Nuestro objetivo en este punto es establecer posibles comparaciones con otras imágenes femeninas ibéricas y más concretamente representaciones juveniles. El criterio que hemos seguido de cara a su exposición, atiende en primer lugar al soporte material de la representación, esto es, esculturas pétreas, a continuación, exvotos metálicos de bronce, así como las cerámicas.

Iniciaremos nuestro recorrido por las imágenes en piedra que se han asociado a las «damitas" de Moixent por su propia definición arquitectónica como nacelas decoradas con figuras humanas representadas en altorrelieve e integradas en monumentos funerarios del tipo pilar-estela. El esquema funcional que observamos en las piezas de Corral de Saus es conocido en el mundo ibérico a través de los ejemplos de las necrópolis de El Prado (LILLO, 1990) y El Poblado de Coimbra del Barranco Ancho (MUÑOZ, 1987; INIESTA, PAGE y GARCÍA CANO, 1987), ambas en Jumilla (Murcia), además de otras posibles piezas de atribución más imprecisa debido a su estado fragmentario de conservación, como las de El Cigarralejo o Cabecico del Tesoro, ya señaladas por ALMAGRO (1983b, 220).

Con respecto a la localidad jumillana, en la necrópolis de El Poblado, hipotéticamente perteneciente a la sepultura núm. 70 , se halló, entre otros elementos, una nacela ornamentada con cuatro personajes en posición yacente, parcialmente conservados, de los cuales, dos de ellos corresponden con seguridad a guerreros. El tercerc se trata de un personaje ataviado con túnica larga, de sexo indeterminado y la cuarta figura no se ha conservado. Se ha propuesto una funcionalidad de nacela que coronaría el monumento tipo pilar-estela restituido (fig. 7) para este yacimiento, datado a mediados del s. IV a.C. en atención a los datos estratigráficos y la fecha de los elementos de ajuar de la tumba (INIESTA, PAGE y GARCÍA CANO, 1987, 58; GARCÍA CANO, 1994). Por su parte, la necrópolis de El Prado documentó un elemento, interpretado por su excavador como 


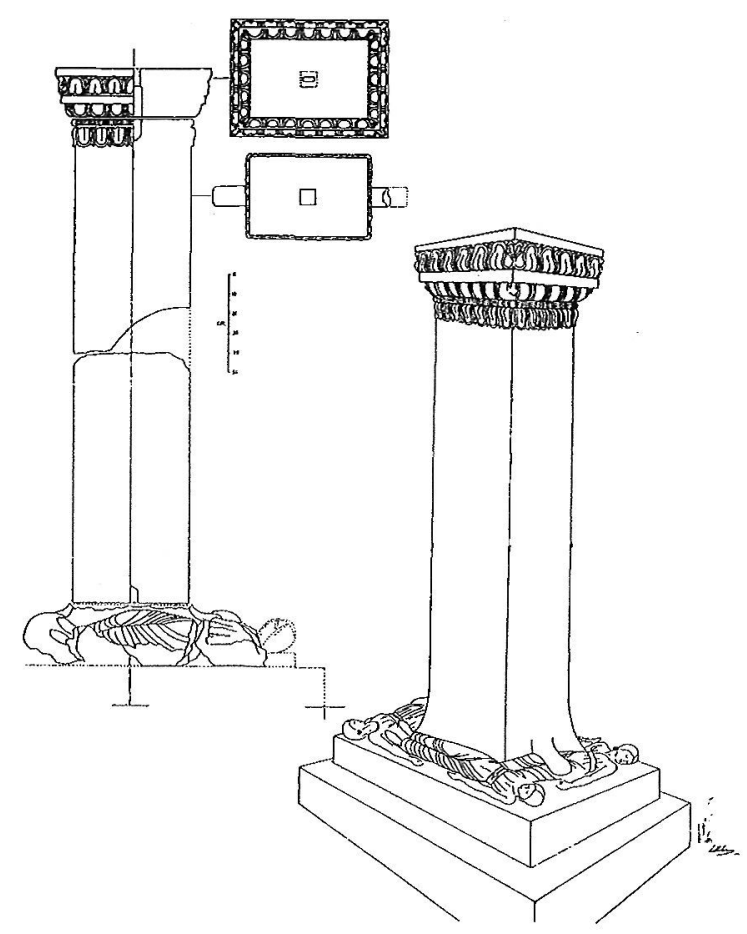

Figura 7: Propuesta de restitución del monumento tipo pilar-estela de la necrópolis de El Prado (Coimbra del Barranco Ancho, Jumilla, Murcia), según Lillo (1990).

base o plinto de una estela, decorado con cuatro figuras femeninas yacentes en altorrelieve, que visten túnicas largas, con pliegues verticales y cinturón ancho. El monumento (fig. 8) se dató en el s. V/IV a.C. de manera imprecisa, en función de una fecha ante quem del último tercio del s. III a.C., proporcionada por el contexto de las esculturas (LILLO, 1990) o bien en el 425-400 a.C., según propuestas más recientes que tienden a rebajar su datación inicial (GARCÍA CANO, 1994, 193). Entre las piezas que se han vinculado a las «damitas» en su atribución a un monumento tipo pilarestela nos encontramos además con un sillar decorado procedente del Cabecico del Tesoro (Verdolay, La Alberca, Murcia), interpretado como gola decorada con figuras femeninas en altorrelieve. En él se puede apreciar un friso decorado con ovas esculpidas, sobre el que descansa un personaje femenino llevando en la mano un ave (PAGE y GARCÍA CANO, 1993, 41, núm. 7).

Pasando, a continuación, a referir otras piezas interesantes en relación a la plástica de las «damitas», en tierras alicantinas fue hallada el pinax o placa de caliza de $25 \mathrm{~cm}$ de altura, concretamente en la tumba núm. 100 de la necrópolis de L'Albufereta (Alicante) (LLOBREGAT, 1972, 150-151, lám. VII y XXX; RU-
BIO, 1986, 115-116, fig. 39) que muestra una escena de despedida con un personaje masculino y frente a él una mujer ataviada con túnica y manto, peinada con trenzas y enjoyada (Lámina IV). Esta composición se ha interpretado en relación con la renovación de las formas artísticas en la plástica del Ibérico pleno y al nuevo papel que juega la imagen de la mujer en éstas (ARANEGUI, 1994, 130, foto 16).

Otras esculturas que presentan elementos comunes puntuales son la cabecita femenina de El Cigarralejo (CUADRADO, 1984, 266, Lám. 17, 1 y 3; CASTELO, 1990a, 189-190, 467, Fig. 72) que presenta un tocado original (fig. 9.1). Destacaremos el tratamiento de la cabellera, con la división del cabello en dos partes, apreciándose en este caso, los pliegues de una posible tela, bajo el mismo, cubriéndole las trenzas que enmarcan el rostro. Asimismo, apareció un fragmento de cabeza femenina, del que no contamos con documentación gráfica, disponiendo, no obstante, de la descripción donde se alude la presencia de parte del peinado realizado posiblemente a base de trenzas enmarcando la cara, sin descartarse la posibilidad de la presencia de carrilleras (CASTELO, 1990a, 191). Carecemos de contextos arqueológicos para ambas piezas ya que las circunstancias de hallazgo en la necrópolis son desconocidas.

No podemos olvidar citar la serie de esculturas femeninas del Cerro de los Santos (Montealegre del Castillo, Albacete). En este santuario ibérico nos encontramos con paralelos puntuales en elementos de indumentaria largas túnicas con pliegues-, adornos personales -collares, con y sin colgantes, brazaletes en espiral, pendientes, a modo de discos planos- y peinado -trenzas-, en determinados exvotos femeninos, como el núm. 70 del catálogo, que presenta un tocado dotado de velo apoyado directamente sobre la cabeza, con diadema a la que se aplican unos discos colgantes en trenzas (RUIZ BREMÓN, 1989, 134) o la cabecita expuesta en el M.A.N. de Saint Germain-en-Laye (ROUILLARD, 1997, 104, AM 1141), cuya construcción del rostro a modo de óvalo es similar al de la "damita I", sin embargo, no hemos identificado representaciones femeninas que en su conjunto puedan paralelizarse formalmente con las "damitas" de Moixent.

Por su parte, cambiando de ámbito geográfico, la auletris que forma parte del monumento funerario de Osuna (Sevilla) (GARCíA BELLIDO, 1943, Lám. XI-XIV) ofrece similitu- 


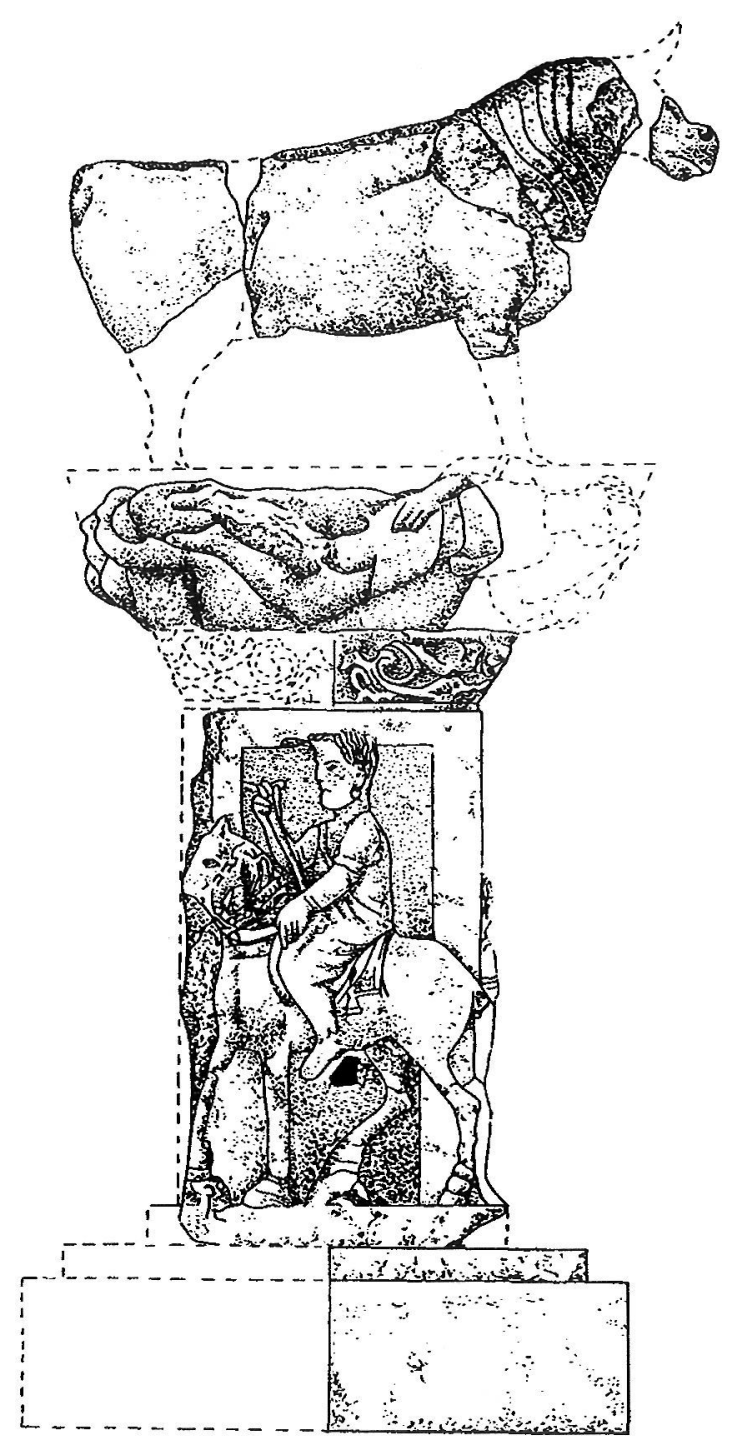

$0 \quad 10 \quad 20 \mathrm{~cm}$

Figura 8: Propuesta de restitución del monumento tipo pilarestela de la necrópolis de EI Poblado (Coimbra del Barranco Ancho, Jumilla, Murcia), según García Cano (1994).
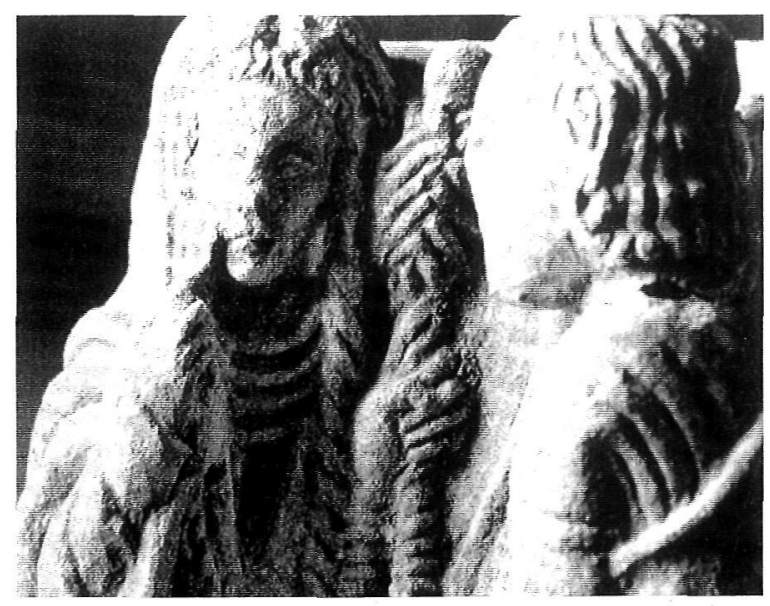

Lámina IV: Dama de La Albufereta (Alicante) (Tarradell, 1968, fig. 100).
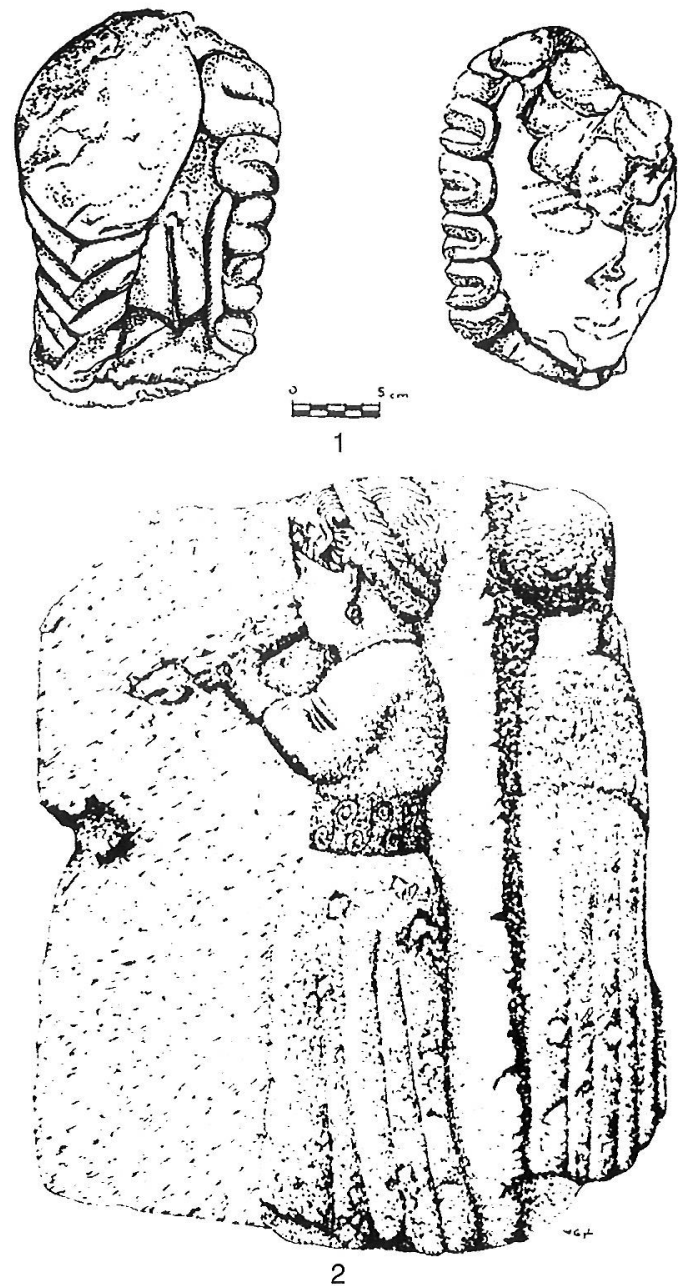

Figura 9: Representaciones femeninas ibéricas: 9.1. Cabecita femenina de la necrópolis de el Cigarralejo (Mula, Murcia), según Castelo (1990). 9.2. Auletris del monumento funerario de Osuna, según Blázquez (1983, il. 89).

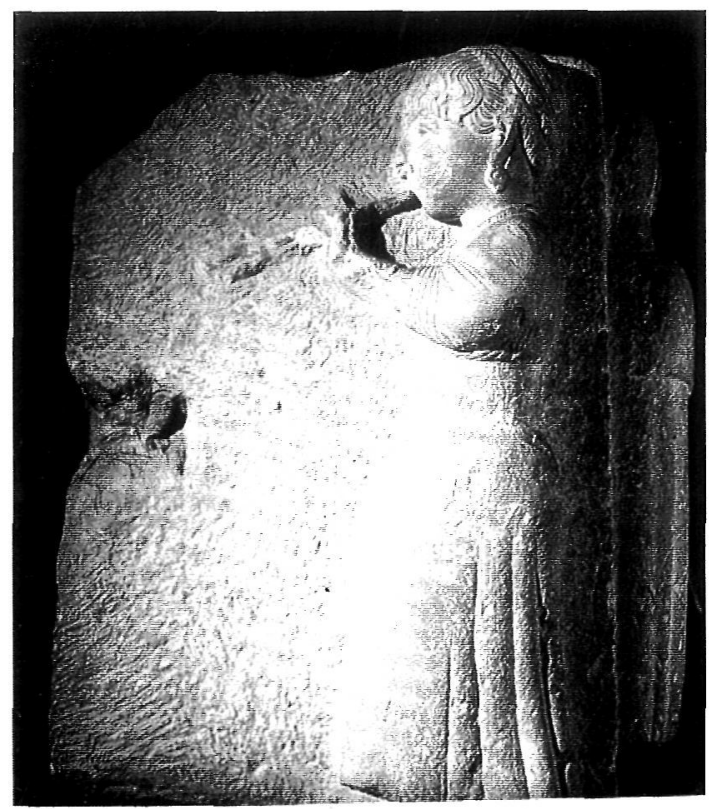

Lámina V: Auletris del monumento funerario de Osuna (Blázquez, 1988, 30). (Foto Ministerio de Cultura). 
des con las «damitas» del Corral de Saus en su consideración como representaciones juveniles, rasgos de indumentaria y peinado (fig. 9.2 y lámina V). A. García Bellido ya destacó la interesante iconografía de adolescente que muestra la decoración de este sillar. Viste esta tañedora del aulós una túnica talar, plisada en parte, de fina tela con escote redondo y mangas por debajo del codo, ceñida en la cintura por un ancho cinturón ricamente decorado. Presenta una especie de flequillo y dos gruesas trenzas que recogen su largo cabello y rodean la cabeza. Como adornos personales, lleva pendientes labrados con doble disco, collar liso de sección circular y brazaletes. Esta figura se ha relacionado, teniendo en cuenta los restantes sillares decorados existentes, con el duelo de los guerreros, como auletris en un ritual sacralizador (OLMOS, TORTOSA e IGUACEL, 1992, 136). El contexto impreciso y controvertido de la pieza, recuperada bajo la muralla de Urso, nos sitúa en una etapa avanzada, al inicio de la romanización, con mucha probabilidad.

Otras piezas de la estatuaria ibérica han sido comparadas con las "damitas» en atención a las trenzas. Así, la esfinge de Casas de Haches (Bogarra, Albacete) (CHAPA, 1985, 66, foto pág. 117) presenta también largas trenzas,

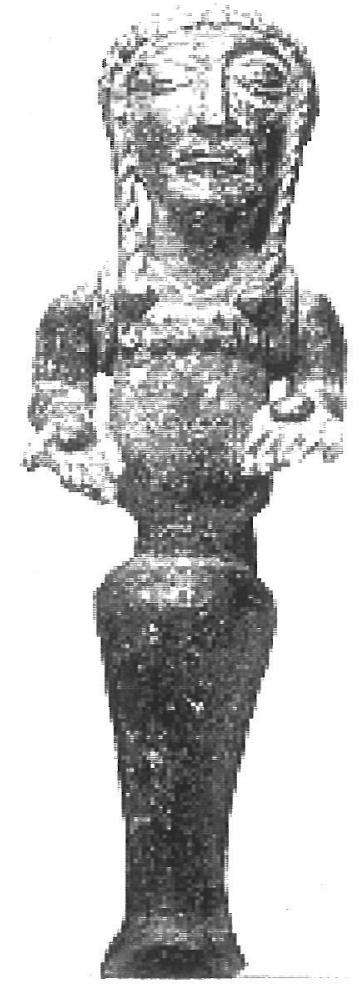

Lámina VI: Exvoto femenino de bronce, procedente de uno de los santuarios de Despeñaperros (Prados, 1988, 86). (Foto G. Nicolini). aunque, su tratamiento es, a nuestro juicio, sensiblemente diferente, más esquemático que las de las "damitas", que son más realistas, volumétricas y logradas desde el punto de vista de su representación.

Una categoría material distinta e interesante sobre la que reflexionar son los exvotos, fundamentalmente de bronce, hallados en los santuarios ibéricos andaluces de Despeñaperros. Tras la revisión del catálogo de las colecciones depositadas en el M.A.N. (PRADOS, 1992), hemos identificado una serie que presenta paralelos con las esculturas que estudiamos aquí. Se trata de un grupo muy homogéneo, identificado fundamentalmente en el Collado de los Jardines, de exvotos femeninos que presentan túnica larga con cintura muy ceñida por un ancho cinturón, cordones en relieve y peinado de largas trenzas, portando palomas -núm. 549- u objetos redondos sin determinar -núms. 550 a 554- o túnica sin cordones, con las palmas extendidas, mostrando un objeto redondeado y plano -núms. 611 a 614-. Igualmente, dentro de una de las antiguas colecciones del museo -M.A.N. D-171- se observa una pieza similar, con túnica lisa, cordones que pasan sobre los hombros y se cruzan en la espalda, brazaletes y en el peinado, un flequiIlo liso - ¿o diadema?- y dos grandes trenzas que caen -núm. 1182-.

En síntesis, se trata de una serie de exvotos que presentan una indumentaria -larga túnica ajustada que permite marcar con claridad las distintas partes del cuerpo- y tocado de perfil curvo, sin cubrir-comunes, adscritos tipológicamente al grupo II de PRADOS (1992, 144), que ofrendan frutos o panes en las palmas, objetos redondos apoyados contra el pecho, un cuenco, etc. (Lámina VI). Algunas de las piezas de esta serie de exvotos de Despeñaperros fue considerada por NICOLINI (1969, pl. XXI, 1-4; IDEM, 1976-1978, 478 . 480 ), dentro del grupo de la portadora de ofrendas con peinado de trenzas. Sus semejanzas de estilo en el vestido y tocado con las esculturas de Corral de Saus fueron resaltadas por Almagro desde la perspectiva del origen y la cronología de éstas últimas, para las que el autor otorga unas fechas de la segunda mitad del s. VI a.C., tal vez hacia su segundo tercio, con influjos de la plástica greco-oriental (ALMAGRO, 1987, 225). A pesar de esto, no obstante, el autor ha reconocido, en otro orden de cosas, el contraste existente entre el detalle del tratamiento de los pliegues en los paños de las esculturas de Moixent y la rigi- 
dez y simetría propias de las obras del arcaísmo final (IDEM, 1987, 224) y, en cualquier caso, la posibilidad de datar a través del estilo cada vez se muestra con más fragilidad en el caso de la cultura ibérica.

Volviendo a la cuestión de los bronces y su cronología, en opinión de L. PRADOS (1992, 161) no es razonable seguir fechando los nuevos hallazgos de estos bronces en función de su semejanza con unas figuras o tipos determinados, adscribibles a los períodos establecidos por NICOLINI en 1976. Es más, esta autora, considera los bronces en otros términos y ha propuesto recientemente fecharlos en época ibérica más avanzada (PRADOS, 1996). Otro testimonio acerca de la datación de estos bronces lo aportó BLÁZQUEZ (1983, Lám. I, $5)$, quien, para uno de los exvotos femeninos del Collado de los Jardines de la serie precedente -con túnica larga y ajustada, cinturón, peinado de trenzas y ofrenda ritual-, que hemos comentado, otorga fechas del s. IV a.C., sin explicar claramente la razón.

La cerámica con decoración figurada del Tossal de Sant Miquel de Llíria (Valencia), que está siendo objeto de una renovación metodológica de análisis, ha avanzando interesantes resultados hasta el momento (ARANEGUI, 1997b; ARANEGUI, BONET, MARTÍ, MATA y PÉREZ BALLESTER, 1996). Una nueva metodología basada en el análisis de formas y motivos, además del contexto y las relaciones con el entorno espacial y temporal, tiende a una interpretación más precisa de la significación de los temas representados en la sociedad ibérica. Partiendo de la nueva documentación que ha proporcionado este proyecto de investigación $^{6}$, se han distinguido representaciones femeninas juveniles en distintas actitudes, como la de tañer el aulós -en la auletris de un lebes del dpto. 41, núm. 19 y un cálato con inscripción sobre el borde del dpto. 14, núm. 3-, bailar junto con jóvenes de género masculino -en un lebes del dpto. 14- y protagonizar escenas de significado nupcial -en un cálato del dpto. 13, núm. 3 y un fragmento de un vaso del dpto. 118, núm. 366- (ARANEGUI, 1997b, figs. 19, 21, 22, 26 y 28), aunque no relacionadas con el mundo funerario. Asimismo, cerámicas procedentes de otros yacimientos han documentado este tipo de representaciones, como en La Serreta (Alcoi, Alicante), donde aparece una auletris (LLOBREGAT, 1972, Lám. XII; NÖRDSTROM, 19691973, 165-166, Láms. 16-18) o en la tinaja de L'Alcúdia d'Elx (Elx, Alicante) en el que una joven podría danzar (BLÁZQUEZ, 1993, fig. 1). Otro tipo de imágenes que muestran algunos vasos de este último yacimiento presentan la representación frontal de un rostro femenino de apariencia juvenil ${ }^{7}$, dentro de las decoraciones llamadas iberohelenísticas (RAMOS FOLQUÉS, 1955, 122, Láms. LXXXVI -LXXXIX), que han sido asociadas a la simbología de la divinidad femenina que aparece en las cerámicas de ElxArchena (RAMOS FERNÁNDEZ, 1991, Láms. II y III).

En síntesis, podemos decir que si bien no contamos con una escultura concreta similar en su conjunto a la de las "damitas", sí que existen paralelos interesantes en cuanto a la definición arquitectónica de las piezas, su labra, indumentaria, tocado, elementos de adorno y ofrenda, grupo de edad, en distintos soportes materiales, como hemos visto.

\section{IV- IMAGEN FUNERARIA, MUJER Y SOCIEDAD}

La dualidad mundo de los vivos/mundo de los muertos puede resultar operativa de cara al estudio de gran parte de las culturas de la antigüedad. Así, la relación existente entre la sociedad que diseña unas pautas funerarias concretas y su reflejo en el registro arqueológico de una necrópolis puede ser esclarecedora al respecto de las características de distintos modelos sociales, teniendo en cuenta, además, las propias carencias y limitaciones del propio registro. Nos parecen, en este sentido, adecuados los planteamientos de J.-P. Vernant acerca de la llamada ideología funeraria, definida como la tarea propia del imaginario social para asimilar el fenómeno de la muerte, civilizarlo e institucionalizarlo, adaptándolo a la vida colectiva. Incluso el autor habla de una política de la muerte en los siguientes términos: " (...) On pourrait presque parler d'une "politique" de la mort, que tout groupe social, pour s'affirmer dans ses traits spécifiques, pour perdurer dans ses structures et ses orientations, doit instaurer et conduire continûment selon des règles qui lui sont propres." (VERNANT, 1982, 7). Desde

\footnotetext{
${ }^{6}$ Agradecemos a la Dra. C. Aranegui las facilidades de acceso a la documentación vinculada al proyecto inicial, así como sus aportaciones al presente artículo.

${ }^{7}$ Las conocidas, de manera poco afortunada, como "peponas" o "tonta del bote", denominaciones que la investigación sobre esa imagen ibérica ha continuado reteniendo hasta la actualidad.
} 
esta perspectiva, es presumible que complejos de imágenes ligadas al ámbito funerario contengan una descripción de la sociedad que las ha producido (D'AGOSTINO, 1988, 218). A partir de estas premisas, la iconografía puede jugar un papel interesante y más concretamente la figuración funeraria. Ésta cobra sentido, entre otros muchos aspectos -rituales, monumentales, etc., dentro de un modelo social con características propias $^{8}$. Así, las imágenes, en este caso funerarias, pueden por tanto, ofrecernos claves interpretativas en apoyo de conocer una sociedad.

Pero hablamos en nuestro objeto de análisis concreto, de imágenes femeninas presentes en la idealización del monumento funerario, por lo que es conveniente matizar algunos aspectos que atañen a la representación del género femenino en la plástica ibérica. Así, en cuanto a las «damitas", no se trata de las clásicas damas ibéricas engalanadas y ataviadas con túnica, velo y mantón, peinadas y tocadas con pesados ornamentos en su cabeza, sino que aparecen cuatro jóvenes mujeres, en actitud ritual -ofreciendo granadas-, cuyos posibles signos de juventud distintivos podrían revelarse a través de su peinado de largas y gruesas trenzas que caen a lo largo del cuerpo y la ausencia de determinados elementos típicos de la indumentaria -velo y grueso mantón-, el tocado y el peinado -tocas, etc. sobre el cabello- o adorno personal femenino -grandes rodetes, collares o pendientes muy ornamentalizados-, además de por la propia apariencia en la labra de sus rasgos que ha inducido tradicionalmente a la investigación hacia su consideración como adolescentes. En efecto, la imagen de las «damitas» da un paso más en los esquemas representativos de la plástica monumental ibérica al tratarse de un grupo de edad concreto, la juventud ${ }^{9}$, cargado de valores y usos simbólicos, reuniendo y proyectando un conjunto de maneras de autorepresentación de la sociedad $^{10}$.

En esta línea, nuestro tema se ubica en un segundo momento en relación a la fase plasmada en el ejemplo del monumento de Pozo Moro, donde el personaje enterrado hace suya, a través de la iconografía (ALMAGRO, 1978), la narración legendaria propia de un ciclo mitológico en el que la aparición de la figura femenina se asocia a la divinidad. Un mundo heroico, propio de una etapa arcaica, en el que, además en otros contextos, animales fantásticos -como grifos, esfinges, etc.- o jinetes y caballeros heroizados, decoran las tumbas mo- numentales de personajes, sin duda, socialmente destacados. Las esculturas del Corral de Saus revelan un lenguaje distinto y un nivel socio-cultural diferente, al representar figuraciones femeninas juveniles participando en el ritual funerario 8IZQUIERDO, 1998b).

La iconografía arcaica ática muestra, por su parte, la integración de la mujer en escenas rituales funerarias (FANTHAM, PEET, BOYMEE, POMEROY y SHAPIRO, 1994, 46-49). A su vez, la decoración figurada de los vasos áticos manifestará claramente un cambio temático desde la presencia de la mujer como partícipe en los rituales de la muerte en el s. VI a.C., hasta la incorporación de la imagen de la mujer en distintas escenas, desde finales del s. V a.C., como las de gineceo o tocador, la numerosa serie de composiciones sobre los lecitos de fondo blanco, donde la mujer visita la estela funeraria, etc., que integran plenamente la imagen femenina en el espíritu de la comunidad (BAZANT, 1987, 35-36). A. Pontrandolfo y $A$. Rouveret reafirman la progresiva afirmación de la imagen de la mujer en las representaciones del ritual funerario y la constitución de una iconografía femenina propia en Poseidonia en el s. IV a.C. (PONTRANDOLFO y ROUVERET, 1982, 311; PONTRANDOLFO y ROUVERET, 1992, 459-462). Tambien la iconografía de la serie de estelas funerarias en piedra incorpora representaciones femeninas 8Véase, en esta línea, para una síntesis de la relación entre
el fenómeno de la muerte, el ritual y la iconografía en las
sociedades del mundo antiguo, D'AGOSTINO y SCHNAPP
(1982) y, de manera más general, GNOLI y VERNANT
(1982). Igualmente, D'AGOSTINO (1988) con referencias
bibliográficas para el mundo griego y etrusco fundamental-
mente.

${ }^{9}$ Desde el punto de vista de la antropologia, es interesante la distinción que Van Gennep realizó, en su clásica obra sobre los ritos de paso, entre la pubertad y la llamada pubertad social, considerándolas esencialmente diferentes y sólo convergentes en raras ocasiones (VAN GENNEP, 1986, 78-83). Sin embargo, para la Antigüedad clásica, y más concretamente para el mundo griego; BRUIT ZAIDMAN $(1991,376)$ ha resaltado cómo lo biológico y lo social se asocian estrechamente para el caso de las mujeres, ya que su vida se divide en la adolescencia, concebida como una preparación al matrimonio, la vida del propio matrimonio, determinada por la función reproductora y, posteriormente, el cambio de status a la edad en que ya no es capaz de tener adolescencia, edad a la que escapa de los privilegios y prohibiciones que marcaban su vida social.

${ }^{10}$ En defitiva, nos interesa la concepción de la juventud desde la perspectiva de la historia cultural. Al respecto, cfs. la obra de G. LEVI y J.-C. SCHMITT (1996), que profundiza en la valoración de esta etapa de la vida, liminal, de transición, en distintos periodos de la Historia. 
y de jóvenes muchachas, tal como el ejemplo de la estela de Anfoto, conservada en el M.A.N. de Atenas y datada a mediados del s. V a.C. 440 a.C.-, en la que aparece una joven tocada con un polos que sostiene, a modo de ofrendas rituales, una flor en la mano izquierda y una granada en la derecha. Esta asociación entre una joven mujer y el simbolismo de la granada en un soporte pétreo y contexto funerario como es la estela, es particularmente interesante desde nuestro punto de vista. Por otra parte, no podemos olvidar que los textos clásicos nos ilustran acerca de la integración en la comunidad de jóvenes mujeres, pertenecientes eso sí, a familias nobles y distinguidas, a través de su participación en complejos rituales colectivos religiosos y civiles, danzas corales y grandes fiestas que conciernen al conjunto de la población"1.

\section{V- CONSIDERACIONES FINALES}

La integración de la imagen de la mujer al menos de la mujer mortal- en escenas con cronología arcaica está ausente en el imaginario ibérico. Sin embargo, tal y como ha demostrado un trabajo reciente (ARANEGUI, 1997a) llega un momento en que las representaciones femeninas, en distintas actitudes, se incorporan al imaginario artístico del mundo ibérico. La interpretación de estas imágenes que revelan un nuevo universo femenino, se ha efectuado en clave social para la etapa del Ibérico pleno, partiendo de la tesis de la diversificación de las jerarquías en la sociedad ibérica como resultado del desarrollo de las comunidades ciudadanas, tratándose de mujeres de familias nobles que representan un modelo ideal de la sociedad.

Nuestro interés en este trabajo ha sido documentar el fenómeno de ampliación o incorporación de nuevas imágenes en contextos funerarios y, más concretamente, el concepto de feminización del ritual funerario en la cultura ibérica, cuestión que ya ha sido valorada y analizada en otros contextos del Mediterráneo antiguo como Poseidonia (ROUVERET, GRECO y PONTRANDOLFO, 1983; PONTRALDOLFO $y$ ROUVERET, 1982 y 1992) o Etruria (D'AGOSTINO, 1988). Esta nueva iconografía manifiesta caracteres propios de la sociedad que genera estas imágenes y revela, a su vez, un segundo momento con respecto a una etapa arcaica ibérica anterior. Las "damitas" del Corral de Saus pueden ser interpretadas como la ex- presión monumental de una comunidad jerárquica y organizada, cuya elite se representa a sí misma en la imagen de una mujer explícitamente joven. Estas imágenes -caracterizadas individualmente- plasman, asimismo, un claro simbolismo funerario a través del mostrar y poseer el fruto prolífico de la granada, manifestando el rito de paso al más allá. Pero no podemos olvidar los datos que ofrece el propio contexto arqueológico de las piezas reempleadas.

Estas esculturas forman parte de un monumento funerario -como hemos visto-, algunos de cuyos elementos se amortizan en una necrópolis de empedrados tumulares y cremaciones en hoyo de cronología avanzada -siglos III y II a.C.-. Ante las evidencias de remoción de fases distintas, las hipótesis que se plantearon los primeros investigadores a la hora de establecer la cronología de la "tumba de las damitas", reiteran las fechas propuestas para la construcción y vigencia de la de las "sirenas" (FLETCHER, 1975, 112 v. APARICIO, 1982, 42). Así, nuestra propuesta se sitúa en la línea inicialmente planteada por D. Fletcher y E. Pla, quienes dataron la construcción de estas tumbas de un modo general, a partir de la segunda mitad, finales del s. III a.C. o incluso más adelante (FLETCHER, 1974, 107; IDEM, 1975, 112; FLETCHER y PLA, 1974; PLA, 1977a, 5; IDEM, 1977b, 737; ). Tras el análisis de la documentación existente, observamos que el conjunto se presenta de modo que los bloques escultóricos aparecen claramente reutilizados en una estructura escalonada, no muy diferente a alguna documentada en la necrópolis de El Tolmo de Minateda (ABAD, GUTIÉRREZ y SANZ, 1993, 150 y ss., fig. 3), en la que su parte decorativa ya no cumple ninguna función. Una posible hipótesis ya planteada (IZQUIERDO, 1995b) supone el establecimiento de dos propuestas cronológicas: una para la propia tumba cuadrangular y otra para el conjunto escultórico, necesariamente anterior. Al respecto, la doble datación que ofrece el ajuar cerámico podría ser orientativa. A partir del análisis del contexto arqueológico (IZQUIERDO, 1995), la

\footnotetext{
${ }^{11}$ Véase el clásico ejemplo de las arréforas panatenaicas, jóvenes elegidas entre las familias aristocráticas más respetables y distinguidas. Otras tareas rituales al servicio de la divinidad lo manifiestan las plinteridas y aletridas. En relación con divinidades sacrificiales rituales, cabe señalar el ejemplo de las canéforas y bufonias. Por otra parte, grandes fiestas como las celebradas en honor a divinidades como Artemis en Éfeso o Apolo -las Delia- cuentan con la participación de jóvenes mujeres (BRUIT ZAIDMAN, 1991, 388).
} 
«tumba de las damitas» se fechó, de una manera flexible, entre los ss. III y II a.C., fecha ante quem para la erección del pilar. La vigencia de estas esculturas femeninas, integradas en el conocido monumento funerario se sitúa en la primera mitad del s. IV a.C.

La lectura que hemos realizado de las piezas, desde la perspectiva de la iconografía, unida a las observaciones del registro, nos inclina a pensar que estas piezas no pertenecen en absoluto a una fase arcaica de la cultura ibérica. Damos a conocer, pues, una valoración distinta de estas piezas, que esperamos sea enriquecida y matizada con nuevas aportaciones y sobre cuya interpretación iconográfica e integración monumental seguiremos profundizando en el futuro.

\section{BIBLIOGRAFÍA}

ALMAGRO GORBEA, M., 1978: "Los relieves mitológicos orientalizantes de Pozo Moro». TP, 35, 251-278, Madrid

ALMAGRO GORBEA, M., 1983a: «Pozo Moro. El monumento orientalizante, su contexto cultural y sus paralelos en la arquitectura funeraria ibérica». MM, 24: 177-293.

ALMAGRO GORBEA, M., 1983b: «Pilares-estela ibéricos». Homenaje al Profesor Martín Almagro Basch, Vol. III, 720. Madrid

ALMAGRO GORBEA, M., 1987: «El pilar-estela de las «Damitas de Mogente» (Corral de Saus, Mogente, Valencia)». APL, XVII, 199-228. Valencia.

APARICIO, J., 1976: Necrópolis ibérica del Corral de Saus, Mogente (Valencia). Mogente. Programa Oficial de Fiestas.

APARICIO, J., 1982: «La necrópolis de Corral de Saus y las evidencias de una primera revolución social». Papers de la Costera, 2, 42-45. Xativa.

APARICIO, J., 1984: "Tres monumentos ibéricos valencianos: La Bastida, Meca y el Corral de Saus». Varia III. La Cultura Ibérica, 145-205. Homenaje a Domingo Fletcher Valls. Valencia.

ARANEGUI GASCÓ, C., 1994: "Iberica sacra loca. Entre el Cabo de la Nao, Cartagena y el Cerro de los Santos». REIb., 1, La escultura ibérica, 115-138. U.A.M., Madrid.

ARANEGUI GASCÓ, 1996: «Signos de rango en la sociedad ibérica. Distintivos de carácter civil o religioso". RElb., 2, 91-121. Madrid.

ARANEGUI GASCÓ, C., 1997a: Una dama entre otras. En: Olmos, R. y Tortosa, T. (Eds.), 1997, La Dama de Elche. Lecturas desde la diversidad, 179-186. Colección Linx, núm. 2. Madrid.

ARANEGUI GASCÓ, C. (Ed.), 1997b: Damas y caballeros en la ciudad ibérica: las cerámicas de Llíria (Valencia). Cátedra. Historia/ Serie Menor. Madrid.

ARANEGUI, C., BONET, H., MARTí, M.A., MATA, C., PÉREZ BALLESTER, J., 1996: «La cerámica con decoración figurada y vegetal del Tossal de Sant Miquel (Líria, Valencia): una nueva propuesta metodológica». Iconografía ibérica e Iconografía itálica: Propuestas de interpretación y lectura (Roma, 1993), 153-175. Madrid.

CHAPMAN, R., KINNES, I. y RANDSBORG, K. (Eds.), 1981 The Archaeology of Death. New directions in Archaeology. C.U.P.
A.A.V.V., 1984: La cité des images. Religion et société en Grèce antique. Lausanne.

A.A.V.V., 1987: Images et societé en Grèce ancienne. L'iconographie comme mèthode d'analyse. Actes du Colloque International (Lausanne, 1984). Cahiers d'Archéologie Romande, 36. Lausanne.

A.A.V.V., 1988: La parola, l'immagine, la tomba. Annali, Archeologia e Storia Antica, X, Atti del Colloquio Internacionale di Capri, Napoli.

BAZANT, J., 1987: "Les vases athéniens et les réformes démocratiques». En, A.A.V.V., 1987: Images et societé en GrèceGrèce ancienne. L'iconographie comme mèthode d'analyse, 33-40. Lausanne.

BENOIT, F., 1957: «La «Dama de Elche" aux pavots". APL, T. VI, 149-152. Valencia.

BINFORD, L. R., (Ed.), 1972: “Mortuary Practices: their study and their potencial». An Archaeological Perspective, 20843. Seminar Press. N. York.

BLÁZQUEZ, J.M ${ }^{a}$, 1983: Religiones prerromanas. Primitivas religiones ibéricas II, Madrid.

BLÁZQUEZ, J.Mª 1988: «Historia de la Historiografía del Arte Ibérico. Escultura y bronces». Escultura ibérica. Revista de Arqueología, 20-31. Madrid.

BLÁZQUEZ, J.M ${ }^{\mathrm{a}}$, 1993: “Las danzas sagradas de llici, Alicante". Homenaje a Alejando Ramos Folqués, 65-82. (Elche, 1985). Alicante.

BRUIT ZAIDMAN, L., 1991: «Las hijas de Pandora. Mujeres y rituales en las ciudades». En: DUBY, G. y PERROT, M. (Eds.), 1991: Historia de las mujeres en Occidente. T. I. La Antigüedad., 373-419. Madrid.

BULLOCH, A.W., GRUEN, E. S., LONG, A. A. y STEWARD, A., (Eds), 1993: Images \& Ideologies: Self-definition in the Hellenistic World. University of California Press.

CASTELO RUANO, R., 1990: De arquitectura ibérica. Elementos arquitectónicos y escultóricos de la necrópolis de El Cigarralejo (Mula, Murcia). Murcia. Memoria de Licenciatura.

CUADRADO, E., 1984: «Restos monumentales funerarios de El Cigarralejo». TP, 41, 251-290. Madrid.

CUADRADO, E., 1995: "La dama sedente de EI Cigarralejo (Mula, Murcia)". XXII CNA (Vigo, 1994), 247-250. Zaragoza.

CHAPA BRUNET, T., 1991: «La Arqueología de la Muerte: Planteamientos problemas y resultados". Seminario: Arqueología de la Muerte: 13-33. Fons Mellaria. Cultura pueblo a pueblo.

CHAPMAN, R. W. y RANDSBORG, K., 1981: «Approaches to the Archaeology of Death". En CHAPMAN, KINNES y RANDSBORG, (Eds.), 1981: The Archaeology of Death, 1-24. C.U.P.

D'AGOSTINO, B., 1988: Le immagini e la società in Etruria Arcaica. En: A.A.V.V., 1988: La parola, I' immagine, la tomba. Annali, Archeologia e Storia Antica, X, Atti del Colloquio Internacionale di Capri, 217-225. Nápoles.

D'AGOSTINO, B. y SCHNAPP, A., 1982: Les morts entre l'objet et l'image. En: GNOLI, G. y VERNANT, J.P. (Eds.) La Mort, les morts dans les sociétés anciennes, 17-25. C.U.P.

DE LA BANDERA, $M^{2}$ L., 1978: «El atuendo femenino ibérico II». Habis, 9, 401-440. Sevilla.

FANTHAM, E., PEET H., BOYMEE, N., POMEROY, S.B. y SHAPIRO, H.A., (1994): Women in the classical world. Image and Text. Oxford University Press.

FLETCHER VALLS, D. (Dir.), 1974: "Primera campaña de excavaciones en la necrópolis ibérica del «Corral de Saus", en término de Mogente". La Labor del SIP y su Museo. 1972, 97 y 103-108. Valencia.

FLETCHER VALLS, D. (Dir.), 1975: «Segunda campaña de excavaciones en el "Corral de Saus», de Mogente». La Labor del SIP y su Museo. 1973, 109-112. Valencia. 
FLETCHER VALLS, D., y PLA BALLESTER, E., 1974: "Las esculturas en piedra de «El Corral de Saus» (Mogente)». Bellas Artes, 74, año V, núm. 36, 38-39. Madrid.

FLETCHER VALLS, D., y PLA BALLESTER, E., 1977: «Restos escultóricos de la necrópolis ibérica de Corral de Saus (Mogente, Valencia)». Revista de la Universidad Com. plutense, XXVI, núm. 109 (Homenaje a García Bellido III), 56-62. Madrid.

GARCÍA Y BELLIDO, A., 1943: La Dama de Elche y el conjunto de piezas reingresadas en España en 1941. C.S.I.C. Madrid.

GARCÍA CANO, J.M., 1994: «El pilar estela de Coimbra del Barranco Ancho (Jumilla, Murcia)". RElb., 1, La escultura ibérica, 173-202. U.A.M., Madrid.

GNOLI, G. y VERNANT, J. P. (Eds), 1982: La mort, les morts dans les sociétés anciennes. C.U.P.

HUNTINGTON y METCALF, P., (Eds.) 1979: Celebrations of death. The antropology of Mortuary ritual. C.U.P.

INIESTA, A., PAGE, V. y GARCÍA CANO, J. M., 1987: 10 Años de Excavaciones en Coimbra del Barranco Ancho. Jumilla. Consejería de Cultura, Educación y Turismo de Murcia. Murcia.

IZQUIERDO, $\mathrm{M}^{\mathrm{a}}$ I., 1995a: El contexto arqueológico de la necrópolis ibérica del Corral de Saus (Moixent, Valencia). Tesis de Licenciatura inédita. Universitat de València.

IZQUIERDO, $\mathrm{M}^{\mathrm{a}}$ I., 1995b: «El contexto arqueológico de las dos grandes tumbas del Corral de Saus (Moixent, Valencia)». Verdolay, 7, Homenaje a Ana Ma Muñoz, 217-237. Murcia.

IZQUIERDO, M ${ }^{\mathrm{a}}$ I., 1997: "Granadas y adormideras en la Cultura ibérica y el contexto del Mediterráneo antiguo". Pyrenae, 28, 65-98. Barcelona.

IZQUIERDO, M ${ }^{\mathrm{a}}$ I., 1998a: Pilares-estela ibéricos. Estudio de un tipo de monumento funerario aristocrático. Tesis Doctoral. Ed. Microficha, Núm. serie 031-2. Universitat de València.

IZQUIERDO, $M^{a}$ I., 1998b: «La imagen femenina del poder. Reflexiones en torno a la feminización del ritual femenino en la cultura ibérica". Actas Congreso Internacional Los Iberos príncipes del poder, 185-193. Barcelona.

LEVI, G. y SCHMITT, J.-C., 1996: Histoire des Jeunes en Occident 1. De l'Antiquité à l'époque moderne. Paris.

LULL, V., y PICAZO, M., I989: «Arqueología de la muerte y estructura social». AEspA., 62, 5-20. Madrid.

LLOBREGAT, E. A., 1972: Contestania ibérica. I. E. A. Alicante.

LLOBREGAT, E. A., 1989: "La nueva Dama ibérica. Sensacional hallazgo en Cabezo Lucero». Historia 16. Año XIV, 154. Febrero. Madrid.

MUÑOZ AMILIBIA, A.Mª., 1987: «La escultura de la necrópolis de Coimbra del Barranco Ancho (Jumilla, Murcia)». APL, XIX, 1, 229-255. Valencia.

NICOLINI, G., 1969: Les bronzes figurés des sanctuaires ibériques. Paris.

NICOLINI, G., 1976-1978: "Quelques aspects du problème des origines de la toreutique ibérique". Ampurias, 38-40, 463-486. Barcelona.

NORDSTRÖM, S., 1969-1973: La céramique peinte ibérique de la province de d'Alicante, I y II. Acta Universitatis Stockholmiensis. VI y VIII, Stockholm.

OLMOS, R., 1996: "Las inquietudes de la imagen ibérica: diez años de búsquedas". RElb., 2, 65-90. Madrid.
OLMOS, R., TORTOSA, T. e IGUACEL, P., 1992: La sociedad ibérica a través de la imagen. Catálogo de la exposición, Centro Nacional de Exposiciones. Ministerio de Cultura. Dirección General de Bellas Artes y Archivos.

OLMOS, R. y TORTOSA, T., 1997: La Dama de Elche. Lecturas desde la diversidad. Colección Lynx, La Arqueología de la mirada, núm. 2. Madrid.

PAGE DEL POZO, V. y GARCÍA CANO, J. M., 1993: «La escultura en piedra del Cabecico del Tesoro (Verdolay, La Alberca, Murcia)». Verdolay, 3, 35-60. Madrid.

PELEJERO FERRER, J., 1973a: «La necrópolis ibérica de Mogente». La Marina, núm. 11: 15- 16. 6 Mayo.

PELEJERO FERRER, J., 1973b: «Las «damas» ibéricas de Mogente». Levante, 27 Julio.

PLÁ BALLESTER, E., 1976: «Necrópolis ibérica del Corral de Saus Mogente, (Valencia). $2^{a}$ campaña», 1973. NAH, Prehistoria, 5, 385-391. Madrid.

PLÁ BALLESTER, E., 1977a: «Excavaciones en la necrópolis ibérica del Corral de Saus (Mogente, Valencia)". Nota Informativa con motivo del Cincuenta aniversario de la fundación del S. I. P. Valencia.

PLÁ BALLESTER, E., 1977b: «La necrópolis ibérica con sepultura de empedrado tumular del Corral de Saus». XIV CNA (Vitoria, 1975), 727-738. Zaragoza

PONTRANDOLFO A., ROUVERET, A., 1982: «ldeologia funeraria e società a Poseidonia nel IV secolo a.C.». En GNOLI, G. y VERNANT, J.-P., (Eds), 1982: La mort, les morts dans les sociétés anciennes, 299-317. C. U. P. Editions de la Maison des Sciences de l'Homme.

PONTRANDOLFO, A., GRECO, E., ROUVERET, A., 1983: «Pittura funeraria in Lucania e Campania. Puntualizzazioni cronologiche e proposte di lettura". DialAr., 91-130.

PONTRANDOLFO A., ROUVERET, A., 1992: Le tombe dipinte di Paestum. Milán.

PRADOS, L., 1988: “Escultura ibérica en bronce». Escultura ibérica. Revista de Arqueología, 82-93. Madrid.

PRADOS, L., 1992: Exvotos ibéricos de bronce del Museo Arqueológico Nacional. Ministerio de Cultura. Madrid.

PRADOS, L., 1996: "Los ritos de paso y su reflejo en la toréutica ibérica». Coloquio Internacional Iconografía ibérica e lconografía itálica: Propuestas de interpretación y lectura (Roma, 1993), 273-282. Madrid.

PRESEDO VELO, F. J., 1982: La necrópolis de Baza. EAE, 119, Madrid.

RAMOS FERNÁNDEZ, R., 1991: Simbología de la cerámica ibérica de la Alcudia de Elche. Museo Monográfico de la Alcudia. Elche.

RAMOS FOLQUÉS, A., 1955: Sobre escultura y cerámica ilicitanas. Estudios Ibéricos, 3-26, Valencia.

RUANO, E., 1987: La escultura humana de piedra en el mundo ibérico. Ed. Encarnación Ruano Ruiz. Madrid.

ROUILLARD, P., 1997: Antiquités de l'Espagne, Louvre et Saint Germain-en-Laye. Musée du Louvre. Ed. RMN. Paris.

RUBIO GOMIS, G., 1986: La necrópolis ibérica de la Albufereta de Alicante, Valencia. A.C.V., Serie Varia, 11.

RUIZ BREMÓN, M., 1989: Los exvotos del Santuario ibérico del Cerro de los Santos. I. E. A., Serie I- Ensayos históricos y científicos, núm. 40. Albacete.

VAN GENNEP, A., 1986 (Reéd.): Los ritos de paso. Taurus. Barcelona.

VERNANT, J.-P., 1982: Introduction. En GNOLI, G. y VERNANT, J.-P., (Eds), 1982: La mort, les morts dans les sociétés anciennes, 1-15. C. U. P. Paris. 